\title{
ÚJABB FORDULAT A LENGYEL BÍRÓSÁGI REFORM ÜGYÉBEN?*
}

\author{
Széles Krisztina ${ }^{1}$
}

Az Európai Unió Bírósága a Bizottság kérelmére ideiglenes hatállyal felhívta a lengyel kormányt, hogy függessze fel a legfelsöbb biróságok nyugdijkorhatárt érintö reformjának végrehajtását, méghozzá visszaható hatállyal a hatályba lépés napjára. Ezzel összefüggésben a reform elötti birói státuszokat állitsa vissza és tartózkodjon új elnök és új birák kinevezésétöl, valamint e körben további intézkedések megtételétöl. ${ }^{2}$

\section{Előzmények}

2017 őszén a lengyel törvényhozás az igazságügyi rendszer átalakítását célzó új jogszabályokat fogadott el. ${ }^{3}$ Már ekkor élés bírálatok övezték a reformokat, ellenzői megkérdőjelezték azok összeegyeztethetőségét a jogállamisággal és a bírói függetlenséggel. Az Európai Bizottság is kifejezte aggodalmát. A Bizottság szerint a tagállamok döntése a bírósági rendszerük átalakítása, azonban a reformok nem járhatnak az uniós jog és a tagállami alkotmányban lefektetett alapelvek sérelmével. A sikertelen párbeszédek, a figyelmen kívül hagyott ajánlások végül kötelezettségszegési eljárás megindítását eredményezték. Az ügy 2018. október 2-án került az Európai Unió Bírósága elé. A Bizottság keresetében az uniós jog megsértésére hivatkozott. Indítványában gyorsított eljárás lefolytatását és a kifogásolt reformokat megelőző állapot helyreállítását kérte.

\section{A vitatott jogszabályi rendelkezések}

Lengyelországban az új legfelsőbb bírósági törvény 2018 áprilisában lépett hatályba. A hatálybalépés napjától a nyugdíjkorhatár 70 évről 65 évre csökkent, ami önmagában aggályokat vet fel a bírói függetlenség kapcsán. Bár a szabályozás értelmében a 65 . életévüket betöltött bírák kérhetik tisztségük meghosszabbítását, azonban ez feltételekhez kötött. Szükséges a státusz további

\footnotetext{
* DOI 10.21867/KjK/2018.4.2.

${ }^{1}$ Dr. Széles Krisztina, doktorandusz, Debreceni Egyetem Marton Géza Állam- és Jogtudományi Doktoris Iskola

${ }^{2}$ A Bíróság elnökhelyettesének a C-619/18. R. sz. Bizottság kontra Lengyelország ügyben hozott végzése

Elérhető:http://curia.europa.eu/juris/document/document.jsf;jsessionid=A7AC65E8BAD7BBFE2 9049F2B209349CB?text $=\&$ docid $=207961 \&$ pageIndex $=0 \&$ doclang $=H U \&$ mode $=$ req $\&$ dir $=\&$ occ $=$ first\&part=1\&cid=6191917 (letöltés dátuma: 2018 . november 20.)

${ }^{3}$ 2017. december 8-i ustawa o Sądzie Najwyższym (a legfelsőbb bíróságról szóló törvény; Dz. U., 2018., 5. tétel) és módosításai
} 
betöltésére irányuló szándéknyilatkozat, valamint orvosi igazolás, mely szerint az egészségi állapotuk lehetővé teszi a további ítélkezést. A harmadik leginkább problémásnak ítélt feltétel -, hogy a köztársasági elnök engedélyezze a mandátum meghosszabbítását.

A reformok értelmében nyugdíjba kellett vonulnia azoknak a bíráknak, akik a hatályba lépésig, de legkésőbb 2018. július harmadikáig betöltötték a 65 . életévüket. Kivételt azok a bírák jelentettek, akik a fent említett hosszabbítást kérelmezték a szándéknyilatkozat, valamint az orvosi igazolás benyújtásával és a köztársasági elnök engedélyét is megkapták.

A jogszabályból kitünik, hogy a köztársasági elnök diszkrecionális joga, hogy megadja-e az engedélyt vagy sem. A döntése nincs kötve feltételekhez, a határozatával szemben nincs lehetőség bírósági felülvizsgálatra. A köztársasági elnök az új rendszerben felhatalmazást kapott, hogy 2019. április harmadikáig saját belátása szerint döntsön a legfelsőbb bíróság létszámának emeléséről is.

A Bizottság szerint a fenti jogszabály-módosításokkal Lengyelország uniós jogot sértett, ezért az Európai Unió Bíróságához fordult a kötelezettségszegés megállapítása iránt.

\section{Az új jogszabályok hatása}

A kifogásolt rendelkezések hatálybalépésével a legfelsőbb bíróság több bíráját nyugalmazták, ideértve az elnököt és két tanácselnököt is. A reformmal érintett huszonkét bíró közül tizenhatan nyújtottak be kérelmet azért, hogy tisztségüket továbbra is betölthessék. Közülük csupán öten folytathatták ítélkezési tevékenységüket, mivel a többiek nem kapták meg a köztársasági elnök hozzájárulását.

A köztársaság elnök jóváhagyta a bíróság létszámának növelését, így a legfelsőbb bíróság létszáma 93-ról 120-ra emelkedett. A nyugdíjazás és a létszámbővítés hatására 44 álláshelyet írtak ki és ennek döntő része már „elkelt”, a bírói kinevezések folyamatban vannak. Az elnöki szék és az új bírói helyek betöltése a legfelsőbb bíróság jelentős átalakulását jelenti. A reformok ellenzői szerint ez komoly aggodalomra ad okot mind a bírói függetlenség, mind a jogállamiság tekintetében.

\section{A Bizottság félelmei, az ideiglenes intézkedés iránti kérelme ${ }^{4}$}

A Bizottság szerint a vitatott rendelkezések végrehajtása magában hordozza az unió által védett értékek - különösen a bírói függetlenség, a tisztességes eljárás és a jogállamiság - sérelmét. Erre tekintettel kérte az Európai Unió Bíróságát,

\footnotetext{
${ }^{4}$ Az Európai Unió Müködéséről szóló Szerződés 279. cikke és a Bíróság eljárási szabályzata 160. cikk (2) és (7) bekezdése alapján
} 
hogy mindaddig, amíg nem születik döntés az uniós jog sérelme tárgyában, hozzon ideiglenes intézkedést a súlyos károk elkerülése érdekében.

Ennek megfelelően a Bizottság kezdeményezte a nyugdíjkorhatárt érintő jogszabályi rendelkezések végrehajtásának a felfüggesztését. Indítványozta, hogy a Bíróság kötelezze a lengyel döntéshozókat a szükséges intézkedések meghozatalára a reformok előtti bírói státuszok visszaállítása érdekében. A Bizottság kérte új elnök és új bírák kinevezésének a megakadályozását, valamint a legfelsőbb bíróság irányításáért felelős személy bármely elnöki tisztséget érintő intézkedésének a tilalmát. A Bizottság kérelmezte továbbá azt is, hogy Bíróság kötelezze a lengyel kormányt, hogy az ideiglenes intézkedésben foglaltakat a végzésétől számított egy hónapon belül teljesítsék. Végezetül a Bizottság kérelmében szerepelt, hogy a Bíróság írja elő Lengyelország számára, hogy havonta tájékoztassa a Bizottságot az ideiglenes intézkedés megtartásáról és az ehhez szükséges intézkedések megtételéröl.

\section{Mikor lehet helye ideiglenes intézkedésnek?}

Az Európai Unió Bíróságának gyakorlata egyértelmü választ ad a feltett kérdésre. Több együttes feltétel fennállása esetén a Bíróság elrendeli az ideiglenes intézkedést.

Az első feltétel az ún. fumus boni iuris. Ez azt jelenti, hogy első látásra mind a ténybeli, mind a jogi alapok legyenek valószínủek. A második követelmény, hogy az ideiglenes intézkedés sürgős legyen. A bírósági gyakorlata szerint akkor sürgős az ideiglenes intézkedés, ha az uniós érdekek súlyos és helyrehozhatatlan kárának veszélye áll fenn. Ez a veszély teszi szükségessé, hogy az ideiglenes intézkedések már a Bíróság végleges határozata előtt kifejtsék hatásukat. A harmadik kritérium, hogy az eljáró bírák az eset minden fennálló érdekét mérlegeljék mielőtt végzést hoznának az ideiglenes intézkedésröl.

\section{A Bíróság végzése és indokolása az ideiglenes intézkedés iránti kérelemről}

A Bíróság elnökhelyettese ideiglenesen helyt adott a Bizottság minden kérelmének az ideiglenes intézkedés iránti eljárás befejező végzéséig. Lengyelország még nem terjesztette elö észrevételeit, így az eljárást befejező végzés meghozatala hónapokat jelenthet. Az elnökhelyettes az uniós jogot érintő súlyos és helyrehozhatatlan kár azonnali bekövetkezésének veszélye miatt indokoltnak látta az ideiglenes intézkedés azonnali elrendelését.

Az elnökhelyettes indokolásában kifejtette az ideiglenes intézkedés feltételeinek a fennállását, illetve azt, hogy miért nem lehet a követelmények hiányát megállapítani.

A fumus boni iuris kapcsán fordított érvelésében előadta, hogy a Bizottság okfejtése első látásra nem tekinthető sem nyilvánvalóan elfogadhatatlannak, 
sem pedig minden jogi alapot nélkülözőnek. Ez alapján nem zárható ki, hogy e feltétel teljesül.

Az elnökhelyettes szerint a második feltétel, vagyis az ideiglenes intézkedés sürgőssége fennáll. Azzal érvel, hogy ha a kötelezettségszegési eljárás eredményeként a Bíróság helyt ad a Bizottság keresetének és megállapítja Lengyelország kötelezettségszegését, az egyben azt fogja jelenteni, hogy minden döntés, mely a jogszabályváltozások alapján született, az uniós jog sérelmét jelenti. Sérti a független bírósághoz ${ }^{5}$ és a tisztességes eljáráshoz való jogot, az EUSZ 2. cikkében felsorolt értékeket, különösen a jogállamisághoz való jogot. ${ }^{6}$ Ezeknek a jogoknak a sérelme önmagában súlyos és helyrehozhatatlan károkat jelent. Az elnökhelyettes szerint a meghozott határozatok jogereje ennek valós kockázatát hordozza. E körülményekre tekintettel az ideiglenes intézkedés sürgőssége megállapítható.

A harmadik kitétel szerint az eljáró bírónak minden fennálló érdeket mérlegelnie kell. Ennek megfelelően az elnökhelyettes számba vette a fennálló érdekeket és ez alapján mondta ki az ideiglenes intézkedés szükségességét. Megvizsgálta a nemzeti érdekeket és úgy ítélte meg, hogy amennyiben végül a Bíróság elutasítja a Bizottság kötelezettségszegés megállapítására vonatkozó keresetét, úgy az ideiglenes intézkedésnek csak halasztó hatása lesz a vitatott jogszabályi rendelkezések végrehajtására. Ez alapján az ideiglenes intézkedés elrendelésével nem kerülnek jelentős veszélybe sem a nemzeti érdekek, sem a kifogásolt törvények célkitüzései. Ellenben ha a Bíróság megállapítja a kötelezettségszegést és a végleges döntésig nincs ideiglenes intézkedés, ami megakadályozná a kifogásolt rendelkezések azonnali alkalmazását, azzal a független bírósághoz való alapvető jog vonatkozásában súlyos és helyrehozhatatlan kár következik be.

\section{A lengyel reakció}

A Bíróság felhívását követően a lengyel igazságügyi miniszter közölte, hogy Lengyelország az Európai Unió tagországaként az uniós jogot tiszteletben tartja és annak megfelelően fog eljárni. A miniszterelnök szerint mielőtt konkrét lépésekre kerül sor, meg kell alaposan vizsgálni a döntést. A miniszterelnök nyilatkozata ellenére a lengyel kormány rövid időn belül elfogadta a Bíróság döntését és ideiglenesen felfüggesztette a folyamatban lévő kinevezéseket.

A legfelsőbb bíróság korábbi elnöke (aki egyébként nem is ismerte el nyugdíjba küldését) felhívást intézett a huszonkét nyugalmazott kollegájához, hogy folytassák igazságszolgáltatási tevékenységüket.

\footnotetext{
5 2018. február 27-i Associação Sindical dos Juízes Portugueses ítélet, C-64/16, EU:C:2018:117

6 2018. július 25-i Minister for Justice and Equality (az igazságszolgáltatási rendszer hiányosságai) ítélet, C-216/18 PPU, EU:C:2018:586, 48. pont
} 


\section{Mi a következő lépés?}

A Bíróságnak meg kell vizsgálnia a lengyel álláspontot is. Az észrevételezés elemzése után meg fogja hozni az ideiglenes intézkedés iránti eljárás befejező végzését. Az egyik lehetséges döntés, hogy a kötelezettségszegési eljárás lezárásáig az ideiglenes intézkedés hatályban marad. A másik lehetőség, hogy a Bíróság az intézkedéseket elveti és a kötelezettségszegési eljárás befejezéséig lehetővé teszi, hogy a vitatott rendelkezéseket alkalmazzák.

$\mathrm{Az}$ ideiglenes intézkedés hatályban tartása egyben azt jelentheti, hogy a Bíróság szerint fennáll az uniós érdekek súlyos és helyrehozhatatlan kárának a közvetlen veszélye. Másik oldalról, ha az ideiglenes intézkedést mellözi, az azt vetítheti elöre, hogy a Bíróság szerint nem kell tartani az uniós jog sérelmétől. Mindez talán a kötelezettségszegési eljárás végkimenetelét is sejtetni fogja.

\section{Források jegyzéke:}

- A Bíróság elnökhelyettesének a C-619/18. R. sz. Bizottság kontra Lengyelország ügyben hozott végzése

- 2017. december 8-i ustawa o Sądzie Najwyższym (a legfelsőbb bíróságról szóló törvény; Dz. U., 2018., 5. tétel) és módosításai

- Az Európai Unió Müködéséről szóló Szerződés 279. cikke és a Bíróság eljárási szabályzata 160. cikk (2) és (7) bekezdése alapján

- 2018. február 27-i Associação Sindical dos Juízes Portugueses ítélet, C-64/16, EU:C:2018:117

- 2018. július 25-i Minister for Justice and Equality (az igazságszolgáltatási rendszer hiányosságai) ítélet, C-216/18 PPU, EU:C:2018:586, 48. pont 